\title{
ECONOMICAL AND ECOLOGICAL FRIENDLY OF GROWTH MEDIA FOR EDIBLE MUSHROOM Pleurotus ostreatus MADE OF THE COCONUT WASTE
}

\section{MEDIA SABUT KELAPA UNTUK PERTUMBUHAN JAMUR Pleurotus ostreatus YANG EKONOMIS DAN RAMAH LINGKUNGAN}

\author{
Margaretta Christita* ANd Ady Suryawan \\ Environment and Forestry Research and Development Institute of Manado \\ Jalan Raya Adipura, Kima Atas, Mapanget, Manado-Sulawesi Utara 95259 \\ ${ }^{*}$ Corresponding author : christita@forda-mof.org; mchristita@gmail.com
}

Diterima 10 Juli 2016 Disetujui 3 Juni 2018

\begin{abstract}
The abundance of coconut waste in North Sulawesi has not been processed and used optimally, then it becomes waste for the environment. Coconut coir processing for planting medium is limited only for coconut peat (coconut husk powder). One drawback in processing coconut peat requires special equipment and the fuel is expensive. This study aimed to compare the use coconut peat and coconut coir as growing medium for white oyster mushroom. Coconut coir was cut $3 \mathrm{~cm} \times 2 \mathrm{~cm} \times 1 \mathrm{~cm}$ in size, while the comparison medium uses a coconut peat. Compositions of both media are coconut coir / coconut peat $83 \%, 16 \%$ ricebran, $1 \%$ limestone, $60 \%$ water. The result showed that coconut coir more productive than coconut peat. Coconut coir media produces 120.62 grams while the coconut peat media weighing 116.11 grams on each harvesting. Based on the result it can be conclude the usage of coconut coir was better compare than coconut peat for cultivation of oyster mushroom.
\end{abstract}

Key words: Coconut waste, coconut coir, coconut peat, media, mushroom

\section{INTISARI}

Kelimpahan limbah sabut kelapa di Sulawesi Utara belum diolah dan digunakan secara optimal, sehingga menjadi limbah bagi lingkungan. Pengolahan sabut kelapa untuk media tanam hanya terbatas pada coconut peat (serbuk sabut kelapa). Salah satu kelemahan dalam mengolah gambut kelapa adalah diperlukan peralatan khusus dan bahan bakar yang mahal. Penelitian ini bertujuan untuk membandingkan penggunaan sabut kelapa (coconut coir) dan serbuk sabut kelapa (coconut peat) sebagai media tanam jamur tiram putih. Sabut kelapa dipotong dengan ukuran $3 \mathrm{~cm} \times 2 \mathrm{~cm} \times 1 \mathrm{~cm}$, sebagai perbandingan digunakan serbuk gambut kelapasebagai media. Komposisi kedua media adalah sabut kelapa / serbuk sabut kelapa 83\%, 16\% ricebran, 1\% batu kapur, 60\% air. Hasil penelitian menunjukkan bahwa sabut kelapa lebih produktif dibandingkan dengan serbuk sabut kelapa. Media sabut kelapa menghasilkan 120,62 gram sementara media serbuk sabut kelapa seberat 116,11 gram pada setiap panen. Berdasarkan hasil penelitian dapat disimpulkan bahwa penggunaan sabut kelapa lebih baik dibandingkan dengan serbuk sabut kelapa untuk budidaya jamur tiram.

Kata kunci : limbah sabut kelapa, sabut kelapa, serbuk sabut kelapa, media, jamur

\section{BACKGROUND}

North Sulawesi province has coconut plantation area of 263,744.69 hectares in 2009, there was an increase to $266,147.36$ hectares in 2010, and become 267,350.79 hectares in 2011 (Pakasi, 2013). The coconut husk mostly uses as fuel for the copra processing. This process cause increasing of $\mathrm{CO}_{2}$ levels. The coconut husk which is not utilized optimally will become waste.
The coconut husk is a waste of coconut plantations that have a lot of potential include: 1) as a briquetting (Nurhadi, 2014), 2) as a geopolymer replacement for cement (Maulidah et al., 2013), and 3) as a medium to grow plants (Hasibuan et al., 2016 and Awang et al., 2009). Coconut husk has nutrients that are environmentally friendly, but as a growing medium its needs to be neutralized using zeolite and dolomite (Tyas, 2000). Cocopeat as a medium for cultivation of oyster mushroom (P.ostreatus) was tested by Astuti 
and Kuswytasari in 2013, while Nurilla et al. (2013) used it as a medium of wood ear mushroom.

Mushrooming or mushroom cultivation refers to the intentional and direct production of mushroom, subtituting wild collection in the field and forests with a harvest in defined condition of growing, resulting in strict quality control, food safety without risk of consumption of poisonous or toxic species, also the guarantees of benefit generated by these fungi (Zied et al, 2011).White oyster mushroom (P. ostreatus) is an excellent option to be cultivated by its natural characteristic. P. ostreatus is easy to cultivate and can be harvested in a month (Ginting et al., 2013). Oyster mushrooms are easiest and least expensive commercial mushroom to grow because they are well known for conversion of crop residues to food protein (Bandopadhyay, 2013), it has delicious taste, high nutritional as well as a good selling pricebecause the cultivation process is relatively simple and inexpensive cultivation technique (De Sequiera, 2011 and Sanchez, 2010). Oyster mushrooms cultivation using colonize bag containing nutrients and media such as sawdust, rice bran, gypsum (CaSO4) and agricultural lime (CaCO3) (Reyeki, 2013).

White oyster mushroom cultivation in Indonesia established using sawdust. Nowadays the demand of white oyster mushroom as food is increasing, but the source of saw dust was decreasing by the time.

References of the coconut husk utilization as oyster mushrooms growth media is still limited in coconut husk powder or coconut peat shape. Coconut peat was made by processing coconut husks into coconut fiber using the machine. Utilization of pieces of coconut husk (coconut coir) is unavailable, so this research purposes to compare the utilization of coconut peat and coconut coir as white oyster mushroom growing medium.

\section{MATERIALS AND METHODS}

Prepare the growth media (colonize bag)

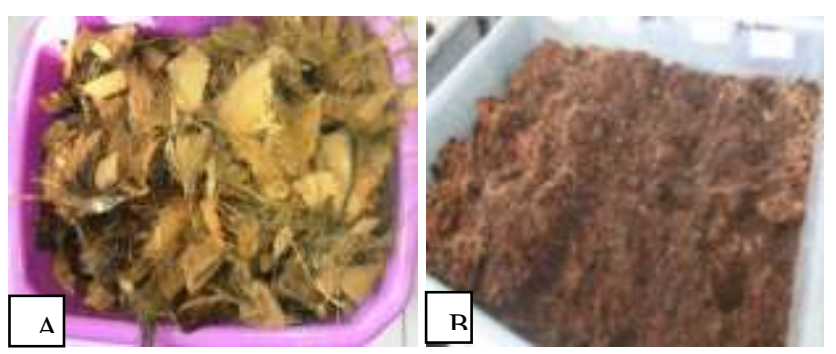

Figure 1. Agricultural waste as growth media(A) coconut coir, (B) coconut peat

\section{Inoculation and incubation}

After cooling stage, the media were inoculated with P.ostreatus (F2 as spawn). Inoculation of P.ostreatus done by put 15 seed from F2 isolate of P.ostreatus into
The research was conducted on April to august 2015, at laboratory of Environment and Forestry Research and Development Institute of Manado, Indonesia. Both coconut coir and coconut peat were collected from the environment of the coconut plantation in Manado City. Coconut coir was prepared by cutting the coconut husk manually into small pieces using a knife. The cutting technique was done crosswise fibers with a size of approximately $3 \mathrm{~cm} \times 2 \mathrm{~cm} \times 1 \mathrm{~cm}$ (Figure 1 ). While the coconut peat taken from coconut fiber factory, it was prepared by mechanical chopping using machine.

The experiment using a completely randomized design with replicates of 10 times for each ingredient. The parameters observed were the growth rate of mycelium, the growth of fruit body and the mean harvest weight of the cartilage and the total harvest of each material tested during the harvest period. Variant analyzes were performed on growth rate of mycelium, growth of fruit body and number of pinheads appearing using $\mathrm{F}$ test, while the Mann-Whitney test was used on the weight of the harvest.

This experiment using coconut coir as the main ingredient of the media. For comparation it also use the growth media mad of coconut peat as main ingredient. Both of growing media was added with other ingredient there are ricebran, limestone and water. Based on previous study in laboratory, composition of media are $83 \%$ the main ingredient, $16 \%$ ricebran, $1 \%$ limestone. Limestone is the raw material as a source of calcium (Ca) and allows to adjust the level of acidity $(\mathrm{pH})$ media. The optimal acidity for growth mushroom is 5.5-6.5. Lime used are agricultural lime $\left(\mathrm{CaCO}_{3}\right)$. The content of calcium and carbon are necessary for growth of mushrooms as well as it increase the value of nutrition. All components were mixed carefully and 50-60\% water were added from total weight of media, or depend on the humidity level of the media. After mixed well, media were filled into the heat resistant plastic bag $(0.2 \times 14 \mathrm{~cm} \times 30 \mathrm{~cm}$ in size). Each colonize bag was filled with $700 \mathrm{~g}$ media. The colonize bag was sterilized using autoclave on $1210 \mathrm{C}, 1 \mathrm{~atm}$ pressure. Each colonize bag could be harvested for 3 times with optimal yield production on the first and second time of harvesting.

each colonize bag. The colonize bag was tied up using plastic pipe and cover it with paper. All the colonize bags were incubated in the dark place with $27^{\circ} \mathrm{C}-28^{\circ} \mathrm{C}$ for three weeks. The research was designed and arranged with 20 replications for each treatment.

\section{Cultivation condition}

After the colonize bag were full with mycelia during incubation, it was transferred to cropping room. The environmental at cropping room was kept illuminated by sunlight, good air circulation and humidity. Watering was done twice a day in the morning and 
afternoon because the weather in Manado mostly warm with temperature about $30^{\circ} \mathrm{C}$.

\section{Harvesting}

The harvesting of mushroom was done after the formation of mushroom had completed. Formation of complete mushroom, especially its body fruit was occurred in a week after the colonize bag had been transferred into the cropping room. A clean scapel was used to detach fruitbodies at the base of stipe from the colonize bag. Weight of the fruiting bodies were recorded for analysis purposes.

\section{Data analysis}

Data analysis was performed by counting the average of growth, shows the mycelial growth and white oyster mushroom fruiting bodies growth curve. $\mathrm{F}$ statistic test used to determine the significant growth between two different growth media.

\section{RESULTS}

The average length of mycelium was $14.5 \mathrm{~cm}$ on the coconut coir medium at day 28 , while the media coconut peat was $13.46 \mathrm{~cm}$. Coconut coir media showed faster mycelial growth than coconut peat (Figure 2), and it is show significant different in Duncan Test to growth of fungal mycelia (Figure 3).

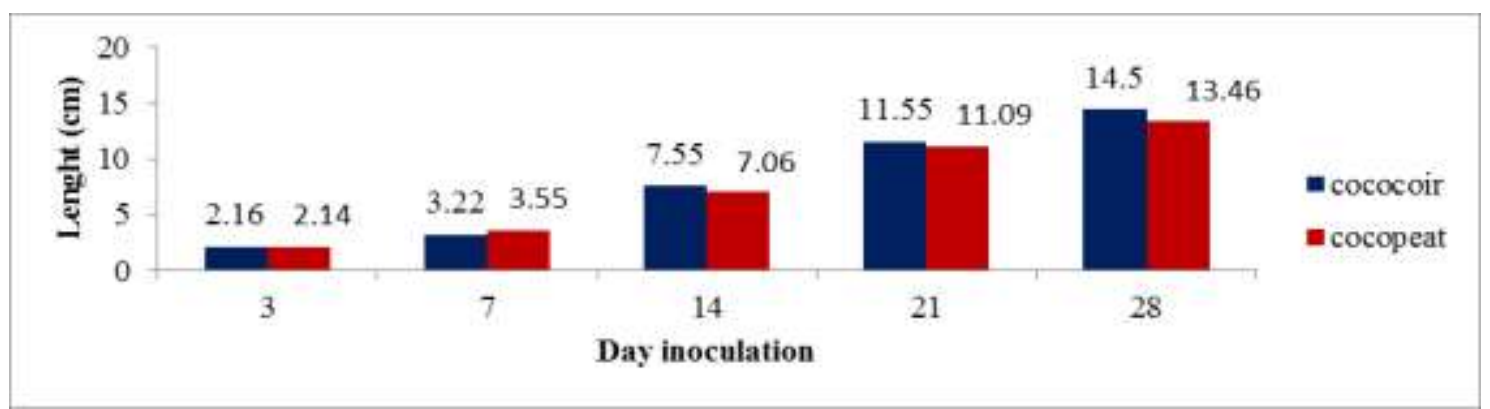

Figure 2. Growth of fungal mycelia on coconut coir compare to coconut peat media

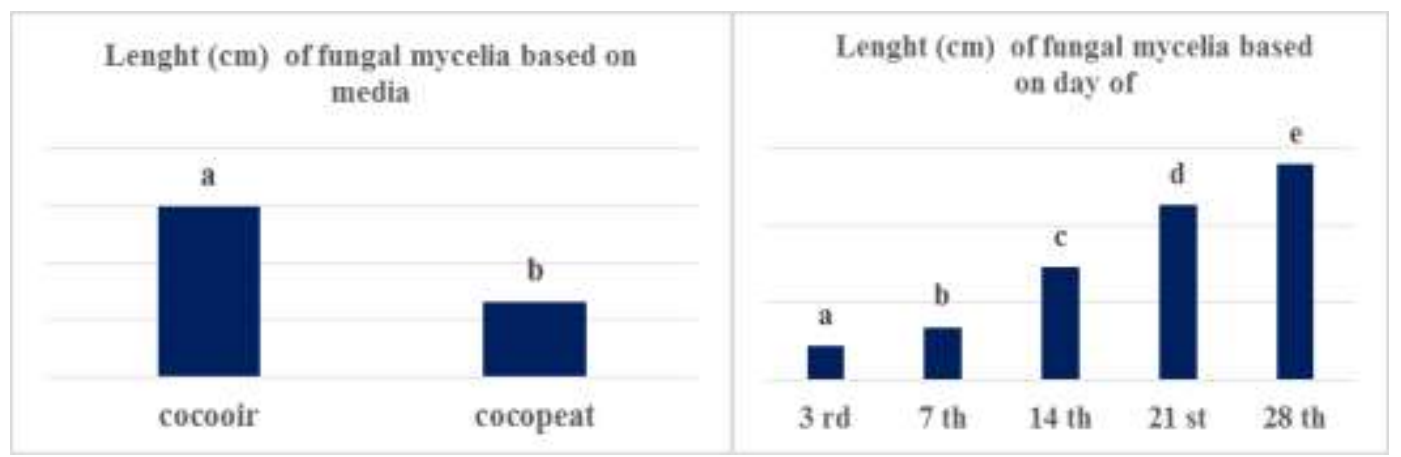

Figure 3. Result of significant difference Duncan test to growth of fungal mycelia (Mean values followed by different letters are significantly different at $5 \%$ level based on Duncan Multiple Range Test)

There were different in size of the average veil diameter fruiting bodies. The average veil diameter of white oyster mushroom which grown on coconut coir media was $0.88 \mathrm{~cm}$ larger than white oyster mushroom which grown on coconut peat media (Figure 4). 


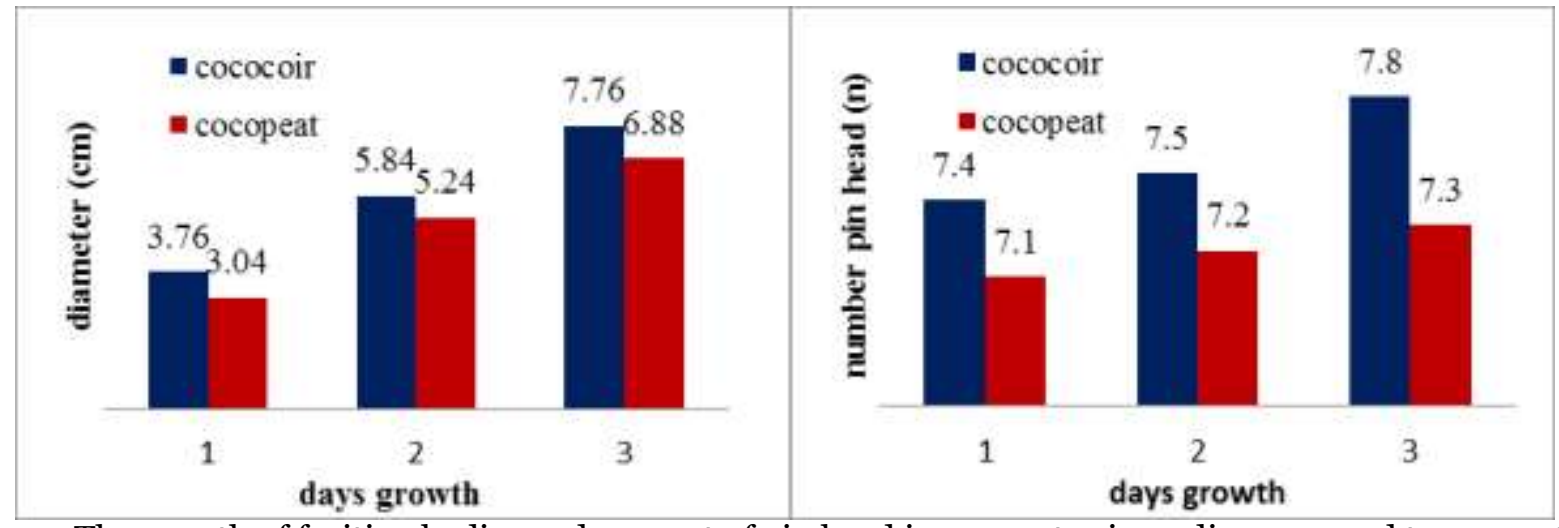

Figure 4. The growth of fruiting bodies and amount of pin head in coconut coir media compared to coconut peat media

The statistic test showed both of F-test for were significant different, while F-test for number of mycelium growth of mushrooms and F-test for pinhead productivities was not significant different diameter growth of fruiting bodies of mushrooms between two different growth medium (Figure 5.)

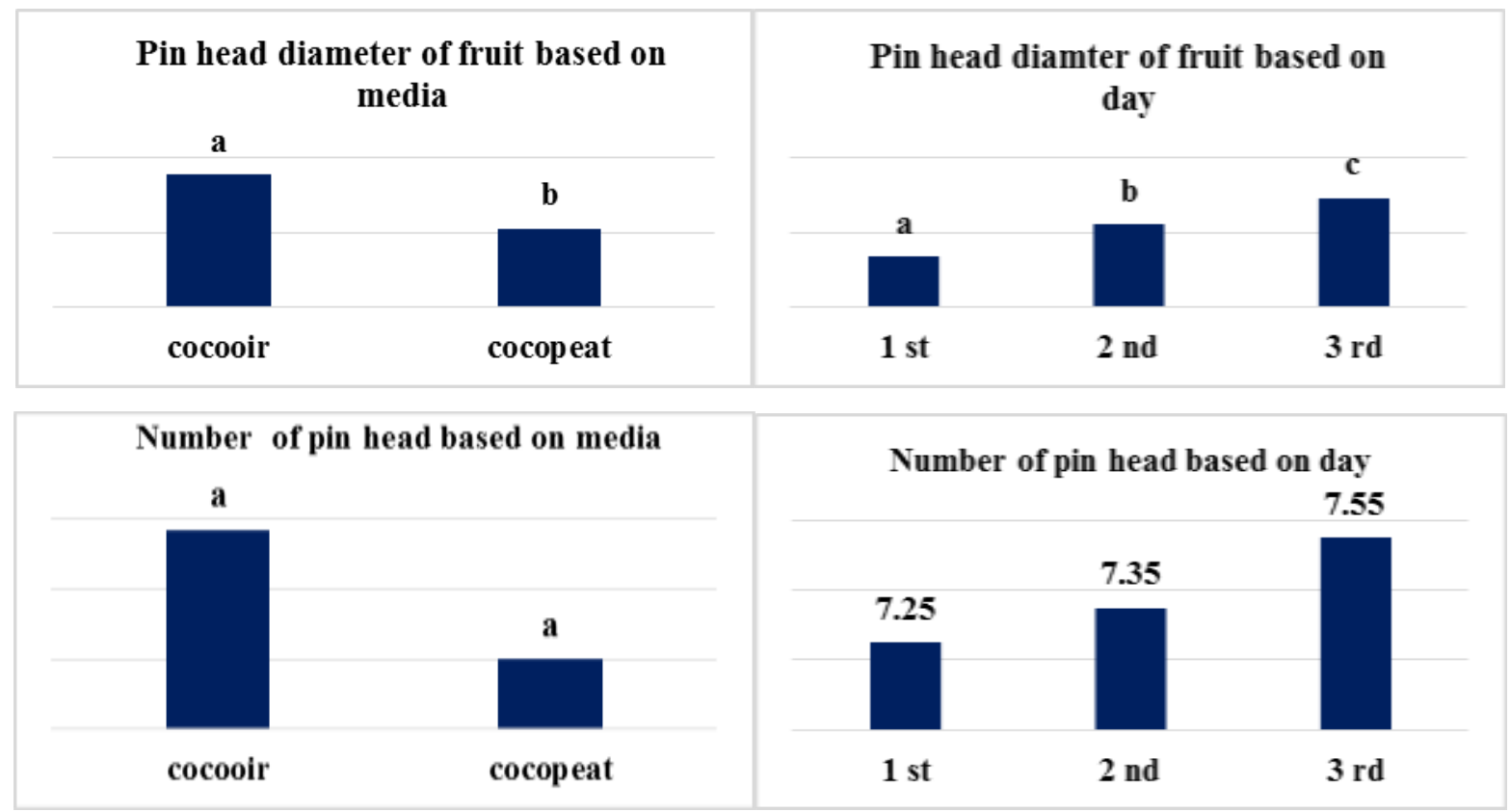

Figure 5. Result of significant difference Duncan test to pin head fruit (Mean values followed by different letters are significantly different at $5 \%$ level based on Duncan Multiple Range Test)

This research showed the yield rate reach weight coir media, while $116.11 \mathrm{~g}$ for mushrooms grow on coconut of $120.62 \mathrm{~g}$ for mushroom which grow on coconut peat media in each colonize bag (Figure 6).

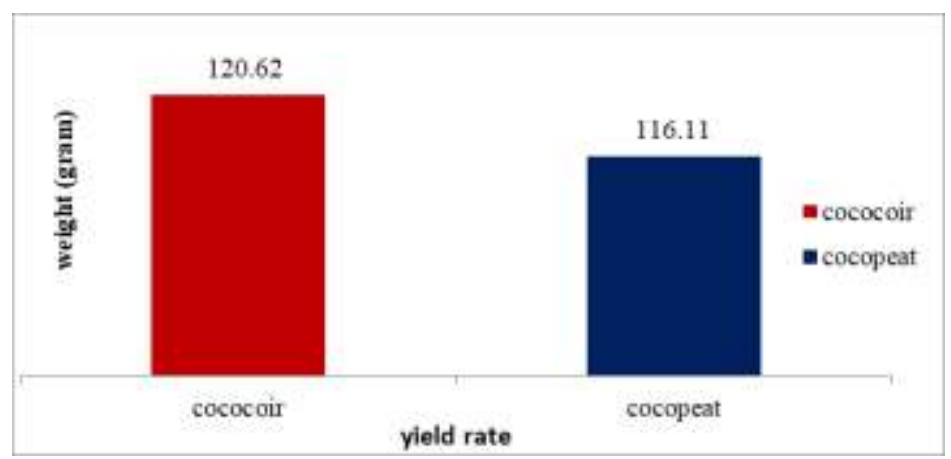

Figure 6. Result of significant difference Duncan test to yield fruit (Mean values followed by different letters are significantly different at $5 \%$ level based on Duncan multiple range test) 
The observations result showed that the coconut coir media was able to make the mycelia sticking stronger and the mushroom fruit does not easily shake (Figure 7.a).
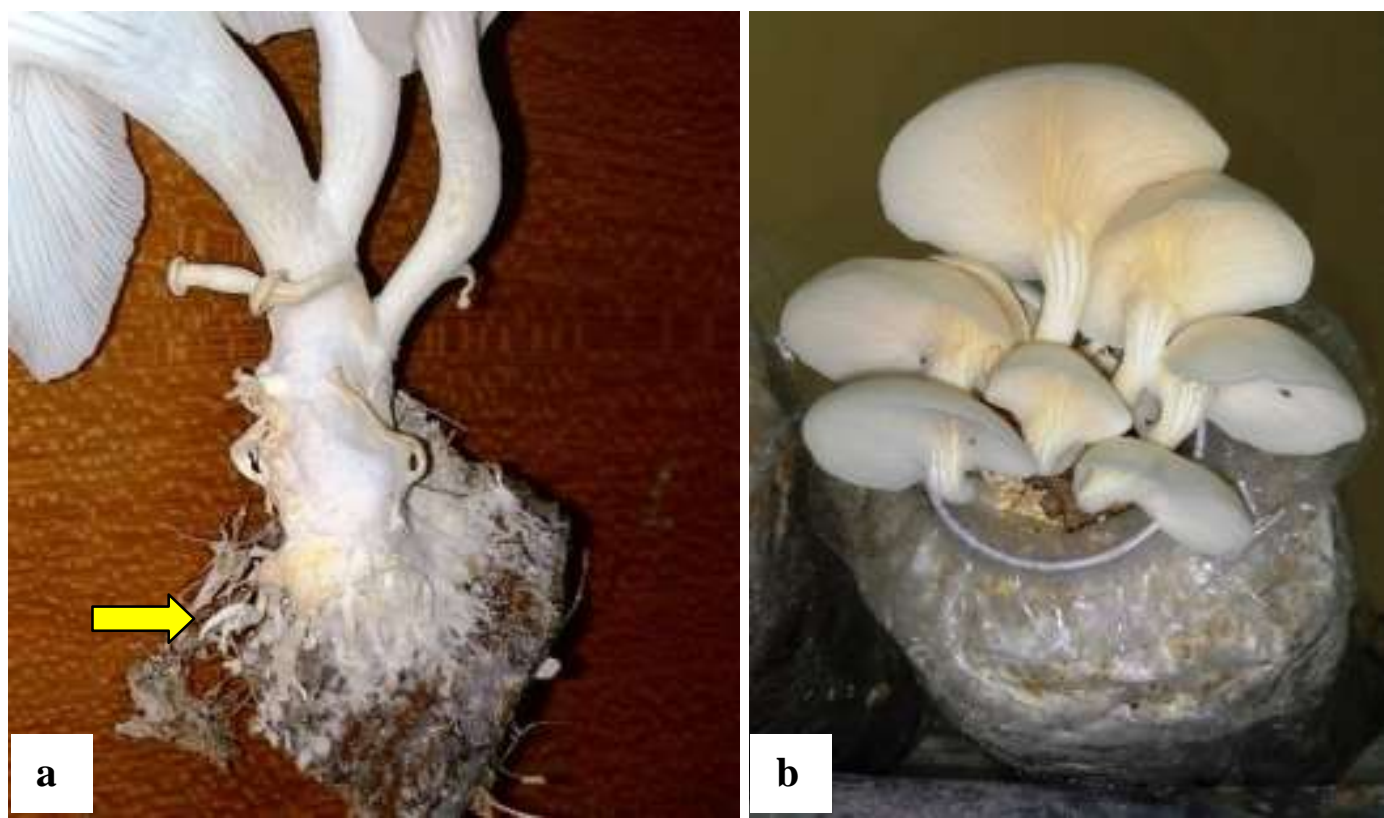

Figure 7. Shape of white oyster mushrooms (a. P.ostreatus was stick stronger on coconut coir media and ; b.White oyster mushroom on coconut coir medium ready for harvesting)

\section{DISCUSSION}

\section{Growth of mycelium and fruiting body production}

Coconut coir as growth media was more effective and economic than coconut peat. Based on the parameters of mycelial growth, both media coconut coir and coconut peat showed same mycelial growth at the beginning. Mycelial growth is the beginning formation of the fungal fruiting bodies. Mycelial growth was influenced by substrate that was used as a growth medium of fungus (Alemu, 2014). Mycelial growth peak occurs when mycelia are able to meet the colonize bag. In this experiment, the colonize bags were fully filled by mycelium on the $30^{\text {th }}$ day after inoculation. The growth of mycelia is highly influenced by nutrient contained in the media. White oyster mushroom needs cellulose, lignin, carbohydrates and glucose (Sharma et al., 2013).

Fruiting body is the edible part of white oyster mushroom, both of the media tested are able to produce the fruiting body of the mushrooms. The primordia formation on both growth media were appeared at 33 days after inoculating, or 3 days after the colonize bag was transferred from incubation room to the cropping room. The primordia formation was affected by humidity and media subtrate (Alemu, 2014). The opening lid of colonize bag performed on the $30^{\text {th }}$ day after inoculation, when the mycelia was colonized whole bag. The number of pin head in first day are more than 7 pin heads / bags and the end for each colonize bag for a harvesting period was 7 pin heads per colonize bag (Figur $5)$. The observation of veil growth has done on the first day when the fruiting body blossom into a veil with a minimum diameter of $3 \mathrm{~cm}$ to $7 \mathrm{~cm}$ (Figure 5) be the fruiting body which ready for harvest. The growth of fruiting body begins with formed of primordia which generally six days after the lid is opened and colonize bags are moved from the incubation chamber into cultivation chamber with watering and light intensity settings.

\section{Morphology}

Coconut coir proved more effective as a growth medium for oyster mushroom, because it has similar morphology to the host tree of white oyster mushrooms in their natural habitat. Naturally, both coconut coir and coconut peat contain materials that required for growth of oyster mushrooms, there are lignin (45.8\%), cellulose (43.4\%), hemicellulose (10.25\%), pectin (3.0\%) (Astuti and Kuswytasari, 2013), however, coconut peat has been separated from the fiber form in which some ingredients have been reduced.

Natural characteristics of coconut peat are good in holding water for humidity maintenance that suitable as a growing medium (Sudomo, 2012). The structure and shape of coconut coir makes it possible to store the water more than coconut peat, which has become a powder. Moreover, the coconut coir shapes is better than coconut 
peat to keep it moist. Maintaining the humidity causes better growth, included long-mycelial growth, veil diameter and produced more yield in each harvesting. Morphologically, the veil of white oyster mushrooms produced at the harvesting is not visible contrast between the white oyster mushroom grown on coconut coir media compare to coconut peat media.

Based on fruiting body production, mushrooms which cultivated on coconut coir showed optimal productivity. The growth of white oyster mushroom fruiting bodies on the coco coir media occurred at 3 to 8 days after the lid of colonize bag was opened. This research showed the growth of fruiting bodies using coconut coir media had an average diameter of $7.96 \mathrm{~cm}$ and weight of $120.62 \mathrm{~g}$ each colonize bag at once harvesting. For comparison, the growth fruiting body on coconut peat media had an average diameter of 7.46 with an average harvest is $116.11 \mathrm{~g}$ for each colonize bag. As comparison, cultivation of white oyster mushroom on saw dust (700 g colonize bag) provides $6,57 \mathrm{~cm}$ of veil diameter in average and $58.71 \mathrm{~g}$ yield each harvesting with three days interval of harvesting (Hariadi et al., 2013). Gonzalez and Catarino (2009) conclude that alkaline water could increase the yield for $40 \%$ than fresh water.

Fruiting bodies production in an industrial mushroom cultivation also affected by provision of fertilizer and insecticide. Saputri (2013) reported that the addition of $1 \%$ dolomite was the best treatment in pink oyster mushroom production. This treatment was an organic cultivation of mushrooms without addition of any chemical component.

Based on observations of oyster mushroom growth on two different growth media, it was known that the coconut coir showed different characteristics compared to coconut peat. Coconut peat shape as a husk, it is similar in size, more fiber, easy to dry, less humid, colonize bags are denser than made from coconut coir. Cocout coir has more fibrous, it has less different in size because it is manually cutting, more humid because its better in keep the water storage, but it less dense compare to coconut peat colonize bag.

The observations result showed that the coconut coir media was able to make the mycelia sticking stronger and the mushroom fruit does not easily shake (Figure 7.a). It is suspected that coconut coir has a resemble shape to a tree trunk or weathered wood where white oyster mushroom grows as a parasite on the natural habitat.

The coconut coir medium for white oyster mushrooms are ecological friendly since it is reduce the agricultural waste in the environment, and it is economically because does not need to pay for the source and does need expensive equipment to make it.

\section{CONCLUSIONS}

Coconut coir is an excellent preference as white oyster mushroom growth medium compared to coconut peat because it gives better results proved optimal mycelial growth at day 28 length of $14.5 \mathrm{~cm}$ and an average harvest weighing 120.62 grams each colonize bag in one harvest.

\section{ACKNOWLEDGEMENT}

The authors would like to thanks to the Head of the Manado Forestry Research Institute, Head of Data, Collaboration and Information for facilitating this research activities.

\section{REFERENCES}

Alemu, F. 2014. Cultivation of Pleurotus ostreatus on Grevillea robusta leaves at Dilla University, Ethiopia. J. of Yeast and Fungal Research 5(99): 74-83.

Astuti, H.K. and N.D Kuswytasari. 2013. Efektifitas Pertumbuhan Jamur Tiram Putih (Pleurotus ostreatus) dengan Variasi Media Kayu Sengon ( Paraserianthes falcataria ). J. Sains Dan Pomits 2(2): $144-148$.

Awang, Y., A.S. Shaharom, R.B. Mohamad dan A. Selamat. 2009. Chemical and physical characteristics of cocopeat-based media mixtures and their effects on the growth and development of Celosia cristata. American J. of Agric. and Bio. Sci. 4(1): 63-71.

Bandopadhyay, S. 2013. Effect of supplementing rice straw with water hyacinth of the yield and nutritional qualities of oyster mushrooms. Micologia Aplicada Intl. 25(2): 15-21.

De Siquiera, F. G., E.T. Martos, R. Da Silva and E.S. Dias. 2011. Cultivation of Pleurotus sajor-caju on banan stalk and Bahia grass based subtrates. Holticultura Brasileira 29(2): 199-204.

Ginting, A. R., N. Herlina and S.Y. Tyasmoro. 2013. Study of growth and production white oyster mushroom in sawdust a baggage substrate. J. Produksi Tanaman 1(2): 17-24.

Gonzales, T. B. and M.C. Catarino. 2009. Cultivation of Pleurotus pulmonarius on substrates treated by immersion in Alkaline water in Guerrero, Mexico. Micologi Aplicada Intl. 21(1): 19-23.

Hariadi, N., S. Lilik and N. Ellis. 2013. Studi Pertumbuhan Dan Hasil Produksi Jamur Tiram Putih (Pleorotus Ostreatus) pada Media Tumbuh Jerami dan Serbuk Gergaji. J. Produksi Tanaman 1 (1): 47-53.

Hasibuan, A.K, A. Dalimunthe dan B. Utomo. 2016. Penggunaan Sabut Kelapa sebagai Penahan Air untuk Mendukung Pertumbuhan Tanaman Sukun 
( Artocarpus Communis Forst ) pada DTA Danau Toba. Peronema Forestry Sci. J. 5 (3): $1-7$.

Maulidah,D., W.P Larasati dan A. Setiawan. 2013. Geopolimer dari Limbah Abu Sabut Kelapa sebagai Pengganti Semen untuk Pembuatan Beton. Universitas Muhammadiyah Jakarta.Unpublish

Nurhadi. 2014. Briket dari Limbah Sabut Kelapa. Diambil kembali dari Universitas Negeri Yogyakarta http://www.uny.ac.id/berita/briket-darilimbah-sabut-kelapa.html diunduh 1 Mei 2015.

Nurilla, N., L. Setyobudi dan E. Nihayati. 2013. The study growth and production of wood ear mushroom (Auricularia auricula) on sawdust and coco peat substrate. J. Produksi Tanaman 1(3): 40-47.

Pakasi, C. B. 2013. Pengembangan Kelapa sebagai Komoditi Unggulan daerah Sulawesi Utara dengan Pendekatan Klaster Industri. Seminar Nasional : Menggagas Kebangkitan Komoditas Unggulan Lokal Pertanian dan Kelautan. Madura.

Paskawati, Y.A., Susyana, Antaresti, dan E.S. Retnoningtyas. 2010. Pemanfaatan sabut kelapa sebagai bahan baku pembuatan kertas komposit alternatif. Widya Teknik 9(1): 12-21.

Reyeki, S. 2013. Pemanfaatan Serbuk Gergajian Sengon (Albizia falcataria) dan Bekatul sebagai Media Tanam Budidaya Jamur Tiram Putih (Pleurotus ostreatus) dengan penambahan serbuk kelapa (Cocos nucifera) [Skripsi]. Surakarta [Indonesia]: FKIP Universitas Muhammadiyah Surakarta.

Sanchez, C. 2010. Cultivation of Pleurotus ostreatus and other edible mushrooms. Apply Microbial Biotechnology 85(5): 1321-1337.

Saputri, R. dan P. Nurmiati. 2018. The Effect of Calcite and Dolomite to Mycelium Growth and Production of Pink Oyster Mushroom ( Pleurotus flabellatus Saccardo ). Online J. Of Natural Science 5(1): 1-10

Shah, Z. A., M. Ashraf and M.I. cehuCh. (2004). Comparative Study on Cultivation and Yield Performance of Oyster Mushroom ( Pleurotus ostreatus ) on Different Substrates ( Wheat Straw , Leaves , Saw Dust ). Pakistan J.of Nutrition, 3(3): 158-160.

Sharma, S., R.K.P. Yadav and C.P. Pokhrel. 2013. Growth and Yield of Oyster mushroom ( Pleurotus ostreatus ) on different substrates. J. on New Biol. Report 2(1): 3-8.

Tyas, S.I.S. (2000).Studi Netralisasi Limbah Sabut Kelapa (Cocopeat) Sebagai Media Tanam. [Skripsi]. Bogor [Indonesia]: Fakultas Teknologi Pertanian Institut Pertanian Bogor.

Zied, D. C., Savoie, J., Pardo-giménez, A., Agronômicas, D. C., Paulista, U. E., Unesp, F. C. A., \& Rey, Q. (2011). Soybean the Main Nitrogen Source in Cultivation Substrates of Edible and Medicinal Mushrooms. In H. El-Shemi (Ed.) Soybean and Nutrition (p. 433-452). Croatia: Intech. 